\title{
7.2 Interleukin-I 7 (IL-I 7) secreting cells in synovial fluid express the "ThI7" master transcription factor RORC and their numbers correlate with CCL20 levels within the joint
} K Nistala*, P Hunter, E Sala-Soriano, J Diss and LR Wedderburn

Address: Institute of Child Health, UCL, London, UK

* Corresponding author

from $15^{\text {th }}$ Paediatric Rheumatology European Society (PreS) Congress

London, UK. 14-17 September 2008

Published: 15 September 2008

Pediatric Rheumatology 2008, 6(SuppI I):SI2 doi:I0.II86/I546-0096-6-SI-SI2

This abstract is available from: http://www.ped-rheum.com/content/6/SI/SI2

(c) 2008 Nistala et al; licensee BioMed Central Ltd.

\section{Background}

Th17 cells are a recently characterised, highly proinflammatory subset of T cells. We have shown that Th17 numbers are elevated in JIA synovial fluid and are significantly higher in extended than persistent oligoarthritis patients [1]. Interestingly we noted a high number of synovial $\mathrm{T}$ cells which produce both IL17 and interferon gamma (IFN $\gamma$ ). We also demonstrated that Th17 are actively recruited by the CCR6 ligand, CCL20, but the clinical relevance of this remained unclear.

\section{Methods}

16 JIA patients had serum and/or synovial fluid samples assayed for CCL20 and corresponding samples of SF mononuclear cells (SFMC) analysed for IL-17 expression. SFMC were sorted by flow cytometry by CCR4 and CCR6 expression and sorted cells were analysed for IL-17 and IFN $\gamma$ expression by intracellular staining. Sorted cells were analysed for expression of the transcriptional regulator of Th17 cells, RORC variant 2, by Q-PCR.

\section{Results}

CCL20 levels were elevated in synovial fluid compared to serum (mean $74 \mathrm{pg} / \mathrm{ml}$ vs $<5 \mathrm{pg} / \mathrm{ml}$ ) and correlated with Th17 numbers in synovial fluid $(\mathrm{r}=0.74, \mathrm{p}=0.0055)$. IL$17+\mathrm{CD} 4 \mathrm{~T}$ cells were limited to the CCR6+ fraction while IL-17+IFN $\gamma+$ double positive cells were enriched within the CCR6+CCR4lo fraction. There was a $>10$ fold increase in RORC2 expression in the CCR6+ compared to CCR4-/ CCR6-CD4+ T cells.

\section{Conclusion}

These results suggest that IL-17 expressing T cells within the joint are bona fide Th17, (RORC+). Elevated levels of CCL20 within the joint may account for the enrichment of both classical Th17 and also the IL-17+ IFN $\gamma+$ T cells seen in JIA.

\section{References}

I. Nistala K, Moncrieffe H, Newton KR, Varsani H, Hunter P, Wedderburn LR: Interleukin-17-producing T cells are enriched in the joints of children with arthritis, but have a reciprocal relationship to regulatory $\mathbf{T}$ cell numbers. Arthritis Rheum 2008, 58(3):875-87. 